\title{
Chemical synthesis and purification of a non-hydrolyzable CTP analog CTPyS
}

\author{
Rejzek $\mathrm{M}^{1^{*}}$ and Tung B. K. Le ${ }^{2}$ \\ ${ }^{1}$ Chemistry Platform \\ John Innes Centre, Norwich, NR4 7UH, United Kingdom \\ ${ }^{2}$ Department of Molecular Microbiology \\ John Innes Centre, Norwich, NR4 7UH, United Kingdom
}

*For correspondence: Martin.Rejzek@jic.ac.uk

\begin{abstract}
Slowly- or non-hydrolyzable analogs of ATP and GTP, for example adenosine 5'-( $\gamma$-thio)triphosphate (ATPyS) and guanosine 5 '-( $(\gamma$-thio)triphosphate (GTPyS), have been widely employed to probe the roles of ATP and GTP in biosystems, and these compounds are readily available from commercial sources. In contrast, cytosine 5'-(y-thio)triphosphate (CTPyS) is not widely available commercially. The recent discovery of ParB as the founding member of a new class of CTPase enzyme (OsorioValeriano et al., 2019; Soh et al., 2019) and the possibility of multiple other undiscovered CTPases necessitate the use of the CTPyS to elucidate the roles of CTP hydrolysis in these systems. Here, we adapt a procedure for the synthesis of modified phosphoanhydrides (Hofer et al., 2015) to chemically synthesize and purify a milligram-scale of CTPyS.
\end{abstract}




\section{Introduction}

A classical approach to the chemical synthesis of $\gamma$-thiophosphate analogs of nucleoside triphosphates is based on S-2-carbamoylethyl thiophosphate activation by diphenyl phosphorochloridate (Goody and Eckstein, 1971). The activated reagent was used to phosphorylate nucleoside diphosphates. The 2carbamoylethyl protecting group was then removed by hydrolysis with sodium hydroxide and the product was purified by DEAE chromatography. This method has not yet been applied for preparation of CTPyS but the isolated yield for ATPyS was reported to be $25 \%$.

A nucleoside diphosphate kinase mediated transfer of a thiophosphate group from a nucleoside $5^{\prime}$-( $\gamma$-thio)triphosphate to a nucleoside 5'-diphosphate was also reported (Goody et al., 1972). This method was applied to enzymatically synthesize CTPyS from ATPyS and CDP (Müller et al., 2000). A partially purified material generated by this transformation was treated with alkaline phosphatase to degrade all material devoid of terminal phosphorothioate, and with dithiothreitol to reduce any dimeric (CTPyS) 2. Multistep HPLC purification yielded a low $\mu \mathrm{mol}$ quantity (about 10\% overall yield) of pure CTPYS, which was characterized by UV and ${ }^{31} \mathrm{P}$ NMR.

More recently, a highly versatile synthesis of nucleoside oligophosphates was reported (Hofer et al., 2015) based on protected phosphoramidites coupling to give mixed $P^{\text {III }}-P^{V}$ anhydrides. In the case of phosphorothioate analogs of nucleotides, the mixed $P^{\prime \prime I I}-P^{V}$ anhydride was then oxidized by sulfur and the protecting group was removed.

Here, we adapt the Hofer et al., (2015) procedure to synthesize and purify a milligramscale of CTPyS.

\section{Results and discussion \\ Synthesis and purification of CTPyS}

Briefly, the synthesis of CTPyS (Scheme 1) started from cytidine 5'-diphosphate (CDP) that was first converted into the corresponding tetrabutylammonium (TBA) salt. Care should be taken not to add excess tetrabutylammonium hydroxide. Ideally, CDP should be provided in a monoacidic form ( $2 \times$ TBA). The exact number of TBA counterion was determined by ${ }^{1} \mathrm{H}$ NMR to be cytidine 5 '-diphosphate $\times 1.44$ TBA salt. This salt was lipophilic enough to dissolve in DMF. The coupling was achieved with bis $(9 \mathrm{H}$-fluoren9-ylmethyl)-diisopropylamidophosphite

$\left((\mathrm{Pr})_{2} \mathrm{NP}(\mathrm{OFm})_{2}\right)$ in the presence of 5(ethylthio)- $1 H$-tetrazole as an activator. The mixture was stirred for 20 minutes at room temperature and after that sulfur was added to oxidise the mixed $\mathrm{P}^{\mathrm{III}} \mathrm{P}^{\mathrm{V}}$ anhydride. The bisfluorenylmethyl-protected intermediate was then obtained by precipitation. Piperidine was used to remove the protecting groups and the crude product was precipitated again as a piperidinium salt. The crude product was purified by strong anion exchange chromatography (SAX) on a Poros $50 \mathrm{HQ}$ using a gradient of ammonium bicarbonate to give CTPyS as an ammonium salt. The volatile buffer was removed by freeze drying. The purity of the final product was determined by SAX to be about $88 \%$. The principal impurity was CDP formed by partial decomposition of CTPyS during the extensive freeze-drying procedure.

\section{CTPyS promotes the engagement between $\mathrm{N}$-terminal domains of Caulobacter crescentus ParB}

Previously, CTPyS has also been shown to promote the self-dimerization of the $\mathrm{N}$-terminal domain ( $\mathrm{N}$-engagement) of ParB proteins (Jalal et al., 2020; Osorio-Valeriano et al., 2019; Soh et al., 2019). Here, we employed site-specific crosslinking of a purified ParB $^{\text {Ccres }}$ (D141C C297S) variant by a sulfhydryl-to-sulfhydryl crosslinker bismaleimidoethane (BMOE) to test if our purified CTPyS can also promote the $\mathrm{N}$ engagement of ParB. BMOE can covalently link symmetry-related $\mathrm{D} 141 \mathrm{C}$ residues together if their inter-distance is within $8 \AA$. Crosslinking products in the presence or absence of nucleotides were analyzed by SDS-PAGE (Figure 1). We observed that CTP and CTPyS, but no other nucleotide triphosphate, enhanced the crosslinking of ParB ${ }^{\text {Ccres }}$ (D141C C297S) (Figure 1), consistent with the previous findings that CTP hydrolysis is not required for $\mathrm{N}$ engagement (Jalal et al., 2020; Soh et al., 2019).

\section{Conclusions}

Here, we report a straightforward procedure for the chemical synthesis and purification of a milligram-scale of a non-hydrolyzable CTP analog (CTPyS). Improved availability of CTPyS will facilitate research by the community into ParB/ParB-like proteins and other CTPases enzymes. 


\section{Experimental procedures}

\section{Materials and equipment}

Sulfur (Cat\# 213292-10G) was purchased from Sigma Aldrich, UK. 5-(Ethylthio)- $1 \mathrm{H}$-tetrazole (Cat\# 493805-2G) was purchased from Sigma Aldrich. Cytidine 5'-diphosphate (Cat\# C9755100MG) was purchased from Sigma Aldrich as a sodium salt and converted into its tetrabutylammonium (TBA) salt by ion exchange on Dowex 50WX8 $\left(\mathrm{H}^{+}\right)$, followed by neutralization with TBA hydroxide (Cat\# 178780$50 \mathrm{ML})$ and subsequent lyophilization. $\mathrm{Bis}(9 \mathrm{H}-$ fluoren-9-ylmethyl)-

diisopropylamidophosphite (Cat\# SC-0057, (iPr) ${ }_{2} \mathrm{NP}(\mathrm{OFm})_{2}$ ) was purchased from SiChem, Germany. Bis-maleimidoethane (BMOE) powder was purchased from ThermoFisher (Cat\# 22323) and was dissolved in DMSO to $20 \mathrm{mM}$. NMR spectra were recorded on a Bruker Advance III $400 \mathrm{MHz}$ spectrometer. Chemical shifts of ${ }^{1} \mathrm{H}$ NMR signals were recorded in $\mathrm{D}_{2} \mathrm{O}$ and were reported with respect to residual solvent peak at $\delta_{H} 4.79 \mathrm{ppm}$. 31P $\{1 \mathrm{H}\} \mathrm{NMR}$ spectra were recorded with ${ }^{1} \mathrm{H}$-decoupling on Bruker $162 \mathrm{MHz}$ spectrometer in $\mathrm{D}_{2} \mathrm{O}$. High resolution accurate mass spectra were obtained using a Synapt G2-Si Q-Tof mass spectrometer using negative electrospray ionisation. HPLC purification was performed on a Dionex Ultimate 3000 instrument equipped with an UV/vis detector. Lyophilization was performed with a Labconco FreeZone Benchtop Freeze Dryer with PTFE Coil. An Eppendorf 5810R benchtop centrifuge was used for centrifugation.

\section{Synthesis of cytosine 5 '-(y-thio)triphosphate (CTPyS)}

Cytidine 5'-diphosphate (CDP) (8.34 mg, 20.7 $\mu \mathrm{mol})$ in ultrapure Milli-Q water $(1 \mathrm{~mL})$ was applied on a column containing Dowex 50WX8 $\left(\mathrm{H}^{+}\right)(1 \mathrm{~mL}$, pre-washed with $\mathrm{HCl}$ and Milli-Q water to neutral $\mathrm{pH})$. The column was eluted with Milli-Q water $(10 \mathrm{~mL})$ while monitoring the $\mathrm{pH}$, and elution was stopped when the $\mathrm{pH}$ returned to neutral. Tetrabutylammonium hydroxide solution ( $\sim 40 \%$ weight in $\left.\mathrm{H}_{2} \mathrm{O}, 41 \mu \mathrm{L}\right)$ was further diluted with water to a final volume of $1 \mathrm{~mL}$. Out of $1 \mathrm{~mL}, 300 \mu \mathrm{L}$ was added to the eluted CDP while monitoring the $\mathrm{pH}$, the final $\mathrm{pH}$ was $\sim 7.0$. Care was taken not to use an excess of TBA hydroxide. The sample was subsequently freeze-dried. The accurate number of counterions was determined by ${ }^{1} \mathrm{H} \operatorname{NMR}\left(\mathrm{D}_{2} \mathrm{O}\right)$ to be cytidine $5^{\prime}$-diphosphate $\times 1.44 \mathrm{nBuN}^{+}$salt (Figure S1).
${ }^{1} \mathrm{H}$ NMR $\left(400 \mathrm{MHz}, \mathrm{D}_{2} \mathrm{O}\right) \delta 8.11(\mathrm{~d}, \mathrm{~J}=7.9 \mathrm{~Hz}$, $1 \mathrm{H}), 6.20(\mathrm{~d}, \mathrm{~J}=7.8 \mathrm{~Hz}, 1 \mathrm{H}), 5.90(\mathrm{~d}, \mathrm{~J}=3.7 \mathrm{~Hz}$, $1 \mathrm{H}), 4.33-4.28(\mathrm{~m}, 2 \mathrm{H}), 4.26-4.21(\mathrm{~m}, 2 \mathrm{H}), 4.16-$ $4.11(\mathrm{~m}, 1 \mathrm{H}), 3.17-3.11(\mathrm{~m}, 11.5 \mathrm{H}), 1.63-1.55$ $(\mathrm{m}, 11.5 \mathrm{H}), 1.34-1.25(\mathrm{~m}, 11.6 \mathrm{H}), 0.89(\mathrm{t}, \mathrm{J}=7.4$ $\mathrm{Hz}, 17.4 \mathrm{H})$.

Next, cytidine 5'-diphosphate $\times 1.44 \mathrm{nBu}_{4} \mathrm{~N}^{+}$ (10.67 mg, $14.2 \mu \mathrm{mol}$ ) was dissolved in $0.5 \mathrm{~mL}$ of dimethylformamide (DMF). To this solution, $(\mathrm{iPr})_{2} \mathrm{NP}(\mathrm{OFm})_{2}(13.6 \mathrm{mg}, 26.2 \mu \mathrm{mol})$ was added and immediately after its dissolution, 5(ethylthio)-1H-tetrazole $(4.8 \mathrm{mg}, 36.8 \mu \mathrm{mol}$ ) was added. The mixture was stirred for 20 minutes at room temperature. After that sulfur (3.0 mg, 94.7 $\mu \mathrm{mol})$ was added and the mixture was mixed vigorously by vortexing for 2 minutes. The bisFm-protected intermediate was then obtained by precipitation with $\mathrm{Et}_{2} \mathrm{O} /$ hexane $5: 1(7.5 \mathrm{~mL})$ and hexane $(2 \mathrm{~mL})$, and pelleted by centrifugation $\left(184 \times \mathrm{g}\right.$, at $4^{\circ} \mathrm{C}$ for 5 minutes). The resulting pellet was washed with $\mathrm{Et}_{2} \mathrm{O}$ and dried under a stream of nitrogen gas and briefly in vacuum. The precipitate was then dissolved in $0.5 \mathrm{~mL}$ of DMF. Piperidine $(25 \mu \mathrm{L}, 21.55 \mathrm{mg}, 253.1 \mu \mathrm{mol}$, $5 \% \mathrm{v} / \mathrm{v}$ ) was added and the mixture was stirred for 15 minutes. The final product was precipitated by adding $3.5 \mathrm{~mL}$ of $1: 5 \mathrm{DCM} / \mathrm{Et}_{2} \mathrm{O}$ 1:5. The mixture was centrifuged at $184 \times \mathrm{g}$ for 5 minutes at $4^{\circ} \mathrm{C}$. The pellet was washed with $\mathrm{Et}_{2} \mathrm{O}$ and dried under a nitrogen stream to give crude CTPyS as a piperidinium salt. The sample was stored at $-80^{\circ} \mathrm{C}$, which is stable for approximately 2 months, until the purification step.

${ }^{31} \mathrm{P}\left\{{ }^{1} \mathrm{H}\right\}$ NMR $\left(162 \mathrm{MHz}, \mathrm{D}_{2} \mathrm{O}\right) \delta 34.2(\mathrm{~d}, \mathrm{~J}=29.5$ $\mathrm{Hz}),-11.4(\mathrm{~d}, \mathrm{~J}=19.7 \mathrm{~Hz}),-23.6(\mathrm{dd}, \mathrm{J}=29.5$, 19.7 Hz). The ${ }^{31} \mathrm{P}$ NMR spectrum (Figure S2) is in good agreement with data published previously, in which CTPyS was synthesized enzymatically (Müller et al., 2000).

\section{Purification of CTPyS}

Next, the sample was dissolved in $1 \mathrm{~mL}$ of Milli$Q$ water and filtered through a $0.45 \mu \mathrm{m}$ PTFE disk filter. CTPyS was purified by strong anion exchange chromatography (SAX) on a Poros 50 HQ column $(10 \times 100 \mathrm{~mm})$ at a flow rate of 7 $\mathrm{mL} / \mathrm{min}$ and UV detection at $265 \mathrm{~nm}$. The elution solvents were $5 \mathrm{mM}$ ammonium bicarbonate (solvent A) and $250 \mathrm{mM}$ ammonium bicarbonate (solvent $\mathrm{B}$ ). The elution started with $0 \%$ solvent B over 2.5 minutes, $100 \%$ solvent B over 7.5 minutes, hold for 4.5 minutes, $0 \%$ solvent B over 
1 minute, and finally the column was equilibrated at $0 \%$ solvent $\mathrm{B}$ for 1 minute. The target compound (CTPyS) was eluted as the last peak at $R_{\mathrm{t}}=12.3 \mathrm{~min}$. Combined CTPyS-containing fractions were freeze-dried to give the final product as an ammonium salt $(2.15 \mathrm{mg}$, yield: $\sim 26.7 \%$, final purity by HPLC: $\sim 88 \%$ ) (Figure S3).

${ }^{1} \mathrm{H}$ NMR $\left(400 \mathrm{MHz}, \mathrm{D}_{2} \mathrm{O}\right) \delta 8.17(\mathrm{~d}, \mathrm{~J}=7.8 \mathrm{~Hz}$, $1 \mathrm{H}), 6.31(\mathrm{~d}, \mathrm{~J}=7.8 \mathrm{~Hz}, 1 \mathrm{H}), 5.99(\mathrm{~d}, \mathrm{~J}=4.2 \mathrm{~Hz}$, $1 \mathrm{H}), 4.44(\mathrm{dd}, \mathrm{J}=4.9,4.9 \mathrm{~Hz}, 1 \mathrm{H}), 4.40-4.38(\mathrm{~m}$, $1 \mathrm{H}), 4.37-4.26(\mathrm{~m}, 3 \mathrm{H})$ (Figure $\mathrm{S4})$.

${ }^{31} \mathrm{P}\left\{{ }^{1} \mathrm{H}\right\}$ NMR $\left(162 \mathrm{MHz}, \mathrm{D}_{2} \mathrm{O}\right) \delta 38.7(\mathrm{bd}, \mathrm{J}=26.7$ $\mathrm{Hz}),-11.4(\mathrm{~d}, \mathrm{~J}=20.3 \mathrm{~Hz}),-23.5$ to $-24.0(\mathrm{~m})$ (Figure S5).

HR-MS (ESI') for $\mathrm{C}_{9} \mathrm{H}_{15} \mathrm{~N}_{3} \mathrm{O}_{13} \mathrm{P}_{3} \mathrm{~S}^{-} \mathrm{m} / \mathrm{z}$ calcd: 497.9544 found: 497.9544 [M-H] $^{-}$(Figure S6).

\section{Construction of pET21b::Ccres parB (D141C C297S)-his 6}

The DNA fragment containing parB (D141C C297S) was chemically synthesized (gBlocks, IDT). The Ndel-HindIII-cut pET21b plasmid backbone and parB (D141C C297S) gBlocks fragments were assembled together using a $2 x$ Gibson master mix (NEB). Gibson assembly was possible owing to a 23-bp sequence shared between the Ndel-HindIII-cut pET21b backbone and the gBlocks fragment. The resulting plasmids were sequenced verified by Sanger sequencing (Genewiz, UK).

\section{Purification of Ccres ParB (D141C C297S)- $\mathrm{His}_{6}$}

The same procedure as previously described (Jalal et al., 2020) was used to purify the ParB (D141C C297S) variant. Purified protein was buffer-exchanged and stored in a storage buffer supplemented with TCEP [100 mM Tris- $\mathrm{HCl}$ pH 7.4, $300 \mathrm{mM} \mathrm{NaCl}, 10 \%$ (v/v) glycerol, and $1 \mathrm{mM}$ TCEP].

\section{In vitro crosslinking assay using a sulfhydryl-to-sulfhydryl crosslinker bismaleimidoethane (BMOE)}

A $50 \mu \mathrm{L}$ mixture of $8 \mu \mathrm{M}$ ParB (D141C C297S) \pm $1 \mathrm{mM}$ NTP $\pm 0.5 \mu \mathrm{M}$ 22-bp parS DNA was assembled in a reaction buffer $[10 \mathrm{mM}$ Tris- $\mathrm{HCl}$ $\mathrm{pH} 7.4,100 \mathrm{mM} \mathrm{NaCl}$, and $1 \mathrm{mM} \mathrm{MgCl}$ ] and incubated for 5 minutes at room temperature. BMOE (1 mM final concentration from a $20 \mathrm{mM}$ stock solution) was then added, and the reaction was quickly mixed by three pulses of vortexing. SDS-PAGE sample buffer containing $23 \mathrm{mM} \beta$ mercaptoethanol was then added immediately to quench the crosslinking reaction. Samples were heated to $50^{\circ} \mathrm{C}$ for 5 minutes before being loaded on $12 \%$ Novex WedgeWell Tris-Glycine gels (ThermoFisher). Protein bands were stained with an InstantBlue Coomassie solution (Abcam) and band intensity was quantified using Image Studio Lite version 5.2 (LI-COR Biosciences). The crosslinked fractions were averaged, and their standard deviations from triplicated experiments were calculated in Excel.

\section{Acknowledgments}

This work was funded by BBSRC grant (BBS/E/J/000PR9791) to T.B.K.L.

\section{References}

Goody RS, Eckstein F. 1971. Thiophosphate analogs of nucleoside di- and triphosphates. $\mathrm{J} A m$ Chem Soc 93:6252-6257. doi:10.1021/ja00752a042

Goody RS, Eckstein F, Schirmer RH. 1972. The enzymatic synthesis of thiophosphate analogs of nucleotides. Biochimica et Biophysica Acta (BBA) - Enzymology 276:155-161. doi:10.1016/00052744(72)90016-2

Hofer A, Cremosnik GS, Müller AC, Giambruno R, Trefzer C, Superti-Furga G, Bennett KL, Jessen HJ. 2015. A Modular Synthesis of Modified Phosphoanhydrides. Chemistry A European Journal 21:10116-10122. doi:https://doi.org/10.1002/chem.20150083 8

Jalal AS, Tran NT, Le TB. 2020. ParB spreading on DNA requires cytidine triphosphate in vitro. elife 9:e53515. doi:10.7554/eLife.53515

Müller MO, Meylan-Bettex $M$, Eckstein $F$, Martinoia E, Siegenthaler PA, Bovet L. 2000. Lipid phosphorylation in chloroplast envelopes. Evidence for galactolipid CTPdependent kinase activities. J Biol Chem 275:19475-19481. doi:10.1074/jbc.M002575200

Osorio-Valeriano $M$, Altegoer $F$, Steinchen $W$, Urban S, Liu Y, Bange G, Thanbichler $M$. 2019. ParB-type DNA Segregation Proteins Are CTP-Dependent Molecular Switches. Cell 179:1512-1524.e15. doi:10.1016/j.cell.2019.11.015 
Soh Y-M, Davidson IF, Zamuner S, Basquin J, Bock FP, Taschner M, Veening J-W, De Los Rios P, Peters J-M, Gruber S. 2019. Self- organization of parS centromeres by the ParB CTP hydrolase. Science 366:11291133. doi:10.1126/science.aay3965 


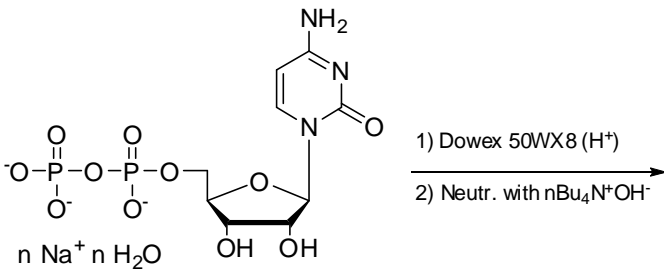

Cytidine 5'-diphosphate

$x \mathrm{n} \mathrm{Na}^{+} \mathrm{n} \mathrm{H}_{2} \mathrm{O}$

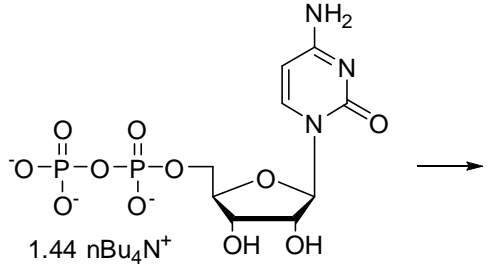

Cytidine 5'-diphosphate $x 1.44 \mathrm{nBu}_{4} \mathrm{~N}^{+}$
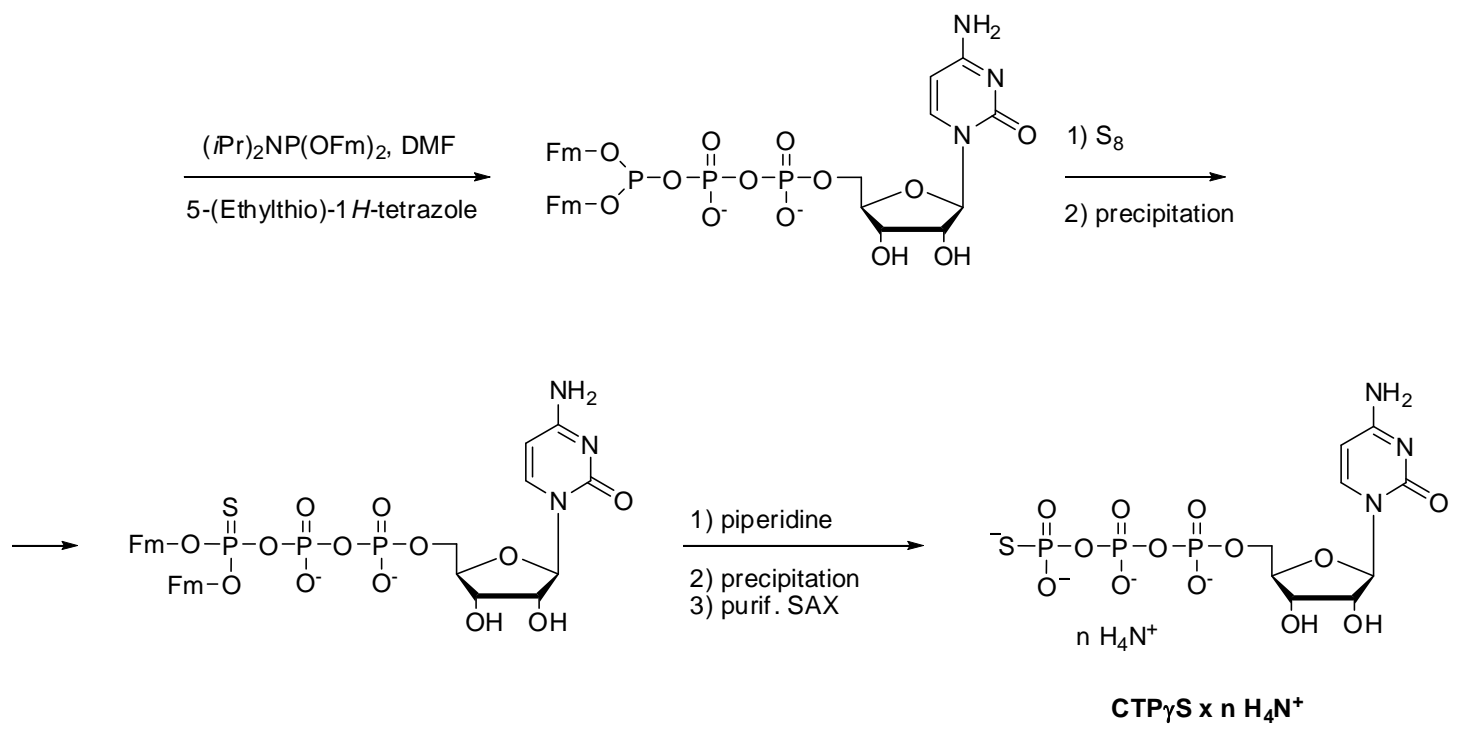

Scheme 1. Synthesis of cytosine $5^{\prime}-(\gamma$-thio)triphosphate (CTPyS) 


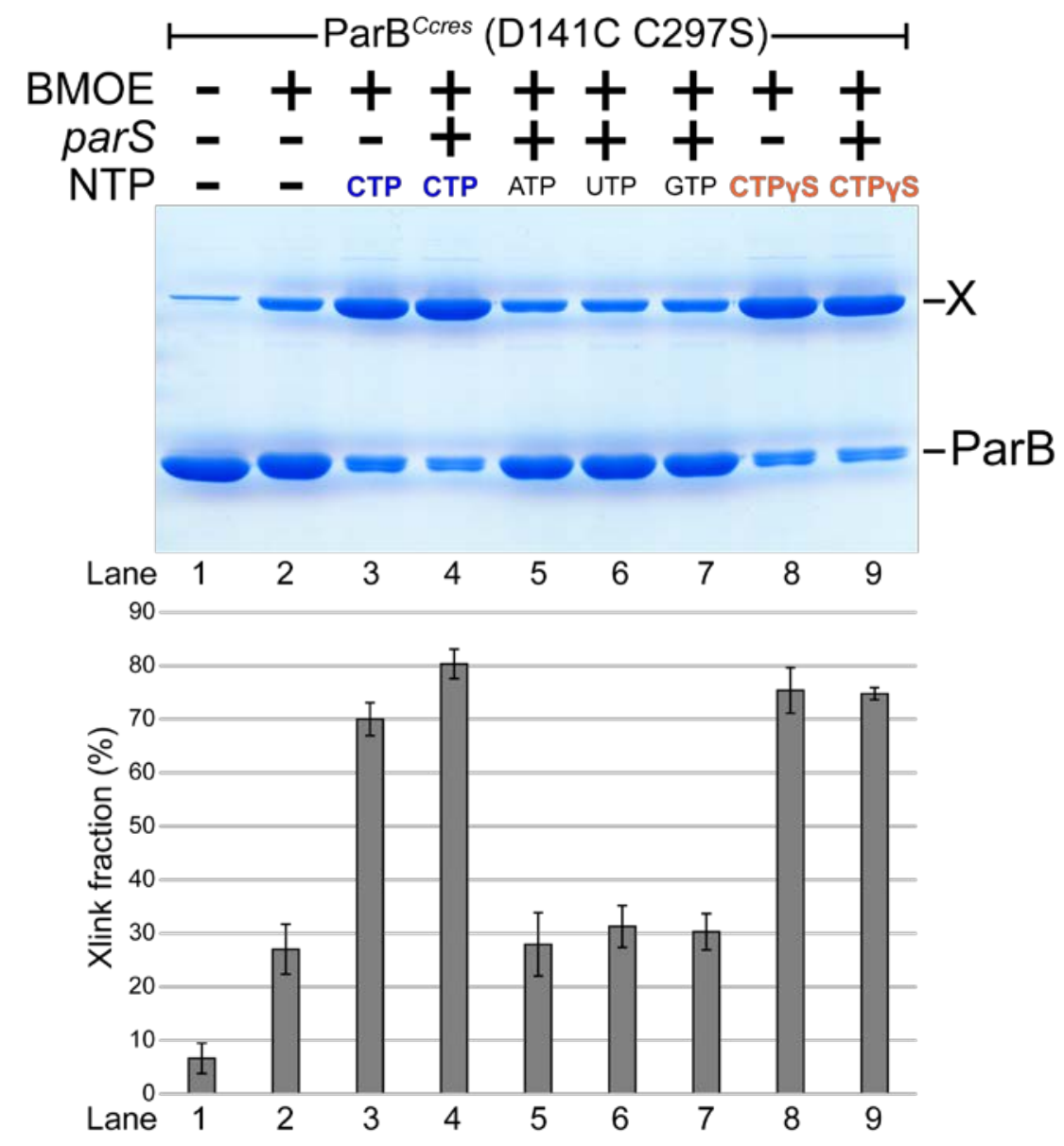

Figure 1. SDS-PAGE analysis of BMOE crosslinking products of $C$. crescentus ParB (D141C C297S) in the presence of CTPyS or other nucleotides triphosphates. A $50 \mu \mathrm{L}$ reaction that contained $8 \mu \mathrm{L}$ of ParB (D141C C297S) $\pm 1 \mathrm{mM} \mathrm{NTP} \pm 0.5 \mu \mathrm{M}$ 22-bp parS DNA in a binding buffer [10 mM Tris- $\mathrm{HCl} \mathrm{pH} \mathrm{7.4,} 100 \mathrm{mM} \mathrm{NaCl}, 1 \mathrm{mM} \mathrm{MgCl}$ ] was incubated for 5 minutes at $22^{\circ} \mathrm{C}$. BMOE ( $1 \mathrm{mM}$ final concentration) was added and the mixture was quickly mixed by vortexing. SDS-PAGE sample buffer was then added to quench the crosslinking reaction. Samples were heated to $50^{\circ} \mathrm{C}$ and analyzed by SDSPAGE. Crosslinked fraction was quantified from triplicated experiments \pm standard deviation. 


\title{
Chemical synthesis and purification of a non-hydrolyzable CTP analog CTPYS
}

\author{
Rejzek $\mathrm{M}^{1^{\star}}$ and Tung B. K. Le ${ }^{2}$ \\ ${ }^{1}$ Chemistry Platform \\ John Innes Centre, Norwich, NR4 7UH, United Kingdom \\ ${ }^{2}$ Department of Molecular Microbiology \\ John Innes Centre, Norwich, NR4 7UH, United Kingdom
}

\section{Supporting Information}

Figure S1. Cytidine 5'-diphosphate x $1.44 \mathrm{nBuN}^{+}$salt: ${ }^{1} \mathrm{H}$ NMR $\left(400 \mathrm{MHz}, \mathrm{D}_{2} \mathrm{O}\right)$ Page 2

Figure S2. CTPyS x n piperidium salt: ${ }^{31} \mathrm{P}\{1 \mathrm{H}\} \mathrm{NMR}\left(162 \mathrm{MHz}, \mathrm{D}_{2} \mathrm{O}\right)$ Page 2

Figure S3. HPLC (Poros $50 \mathrm{HQ}$, ammonium bicarbonate, 5 to $250 \mathrm{mM}$ ) Retention time: $12.3 \mathrm{~min}$.

Final purity (HPLC): $88 \%$ Page 3

Figure S4. CTPyS x $n$ ammonium salt: ${ }^{1} \mathrm{H}$ NMR $\left(400 \mathrm{MHz}, \mathrm{D}_{2} \mathrm{O}\right)$ Page 3

Figure S5. CTPyS x n ammonium salt: ${ }^{31} \mathrm{P}\{1 \mathrm{H}\} \mathrm{NMR}\left(162 \mathrm{MHz}, \mathrm{D}_{2} \mathrm{O}\right)$ Page 4

Figure S6. CTPyS: HR-MS (ESI') Page 4 


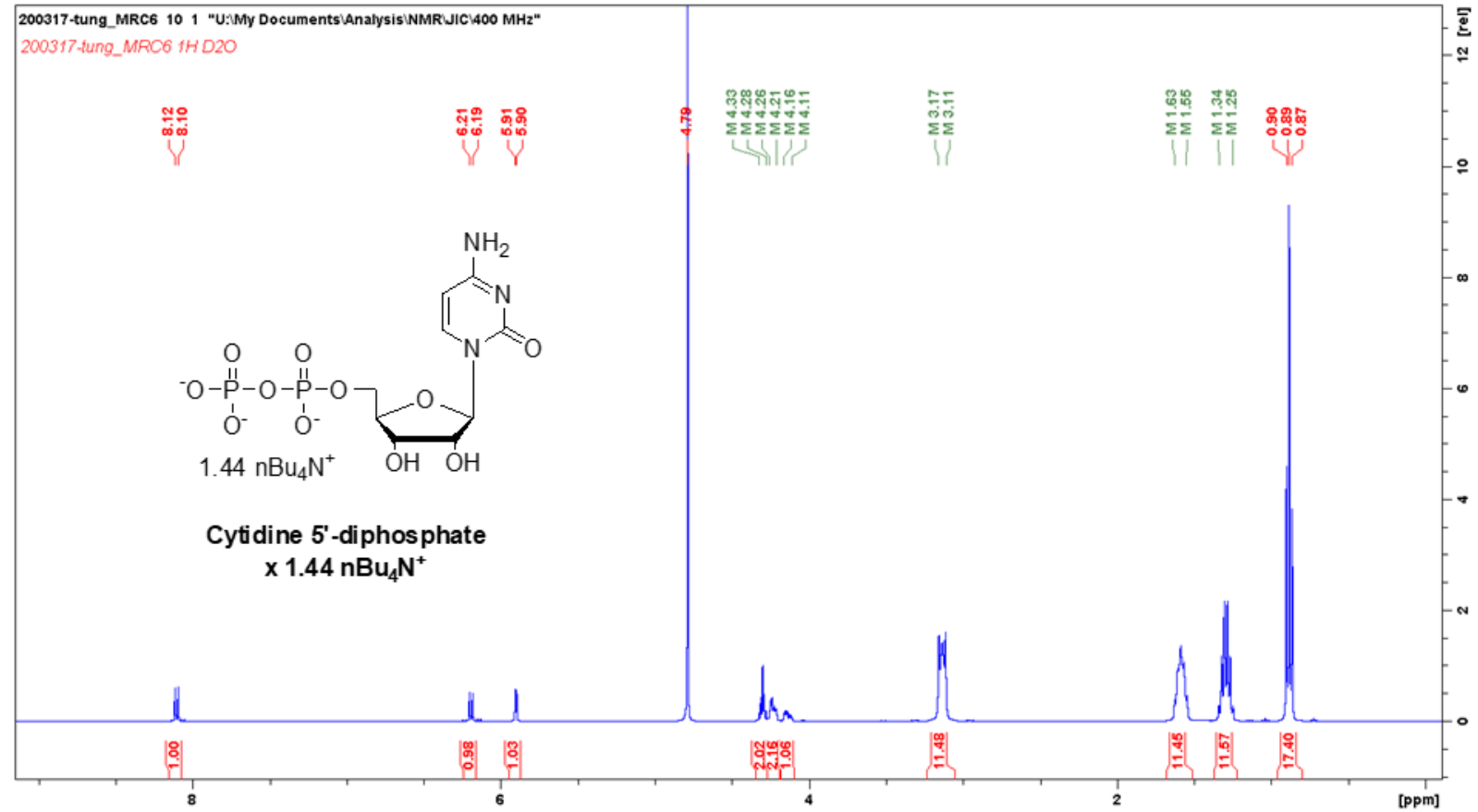

Figure S1. Cytidine 5'-diphosphate x $1.44 \mathrm{nBuN}^{+}$salt: ${ }^{1} \mathrm{H} \mathrm{NMR}\left(400 \mathrm{MHz}, \mathrm{D}_{2} \mathrm{O}\right)$

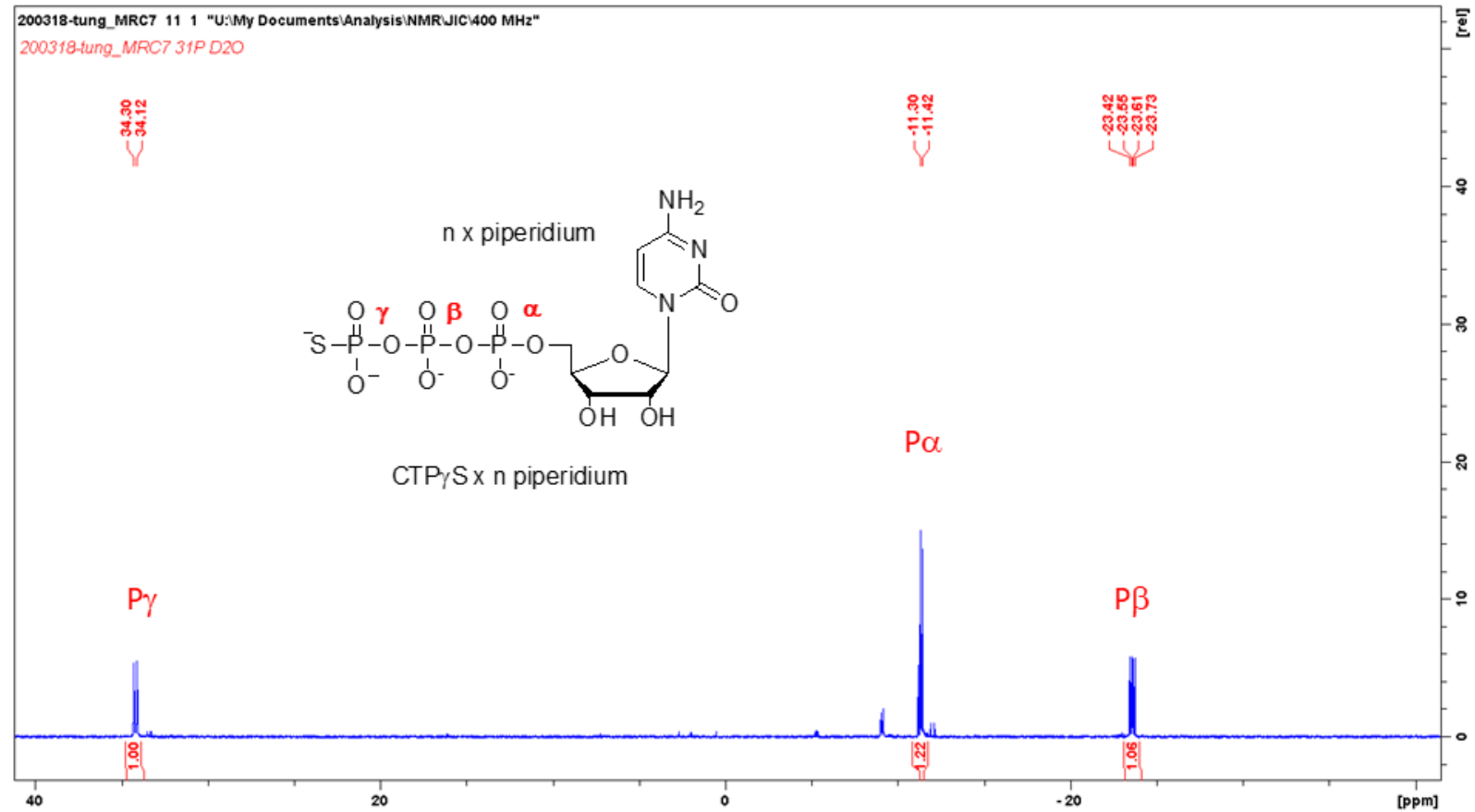

Figure S2. CTPyS x n piperidium salt: ${ }^{31} \mathrm{P}\{1 \mathrm{H}\} \mathrm{NMR}\left(162 \mathrm{MHz}, \mathrm{D}_{2} \mathrm{O}\right)$ 


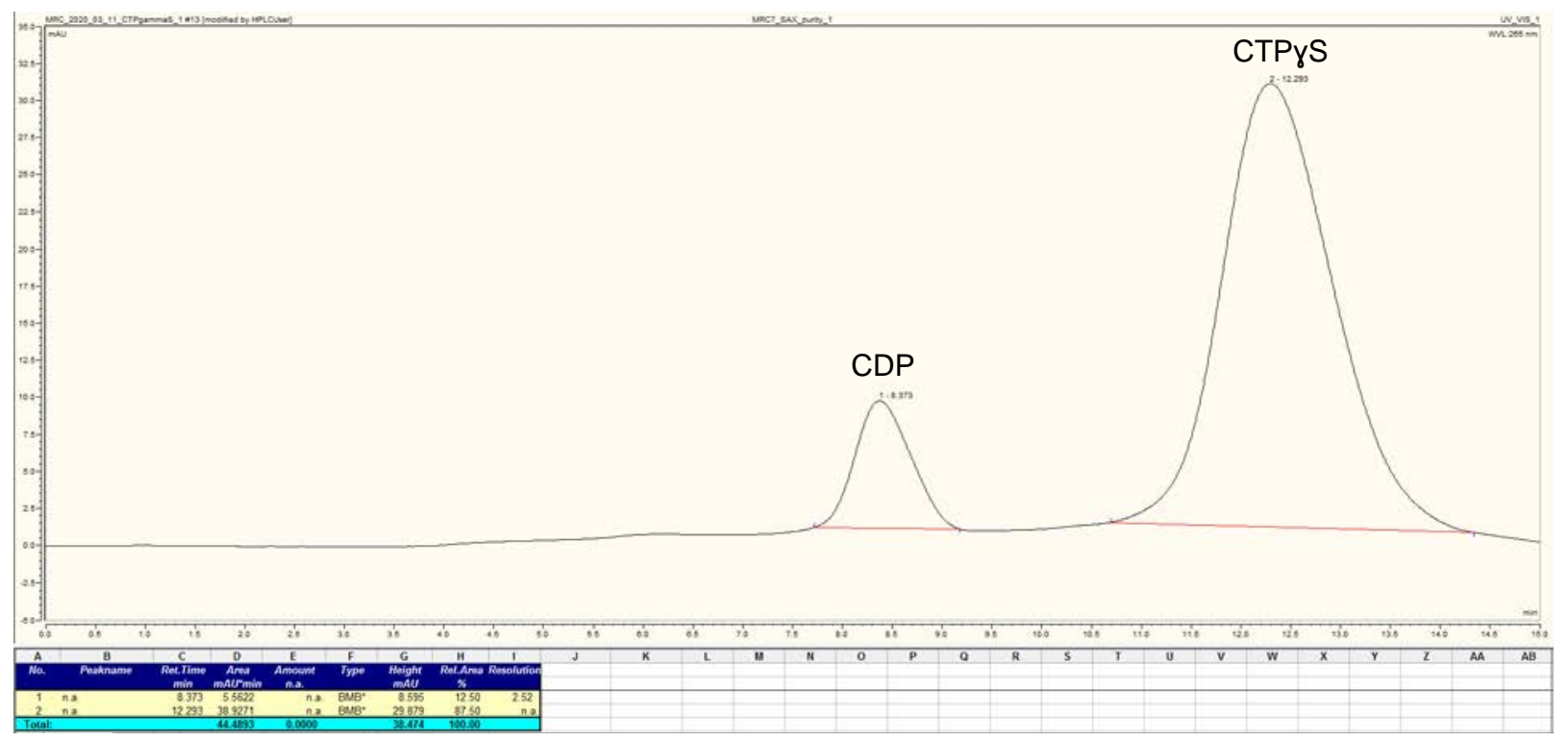

Figure S3. HPLC (Poros $50 \mathrm{HQ}$, ammonium bicarbonate, 5 to $250 \mathrm{mM}$ ) Retention time: 12.3 min. Final purity (HPLC): $88 \%$.

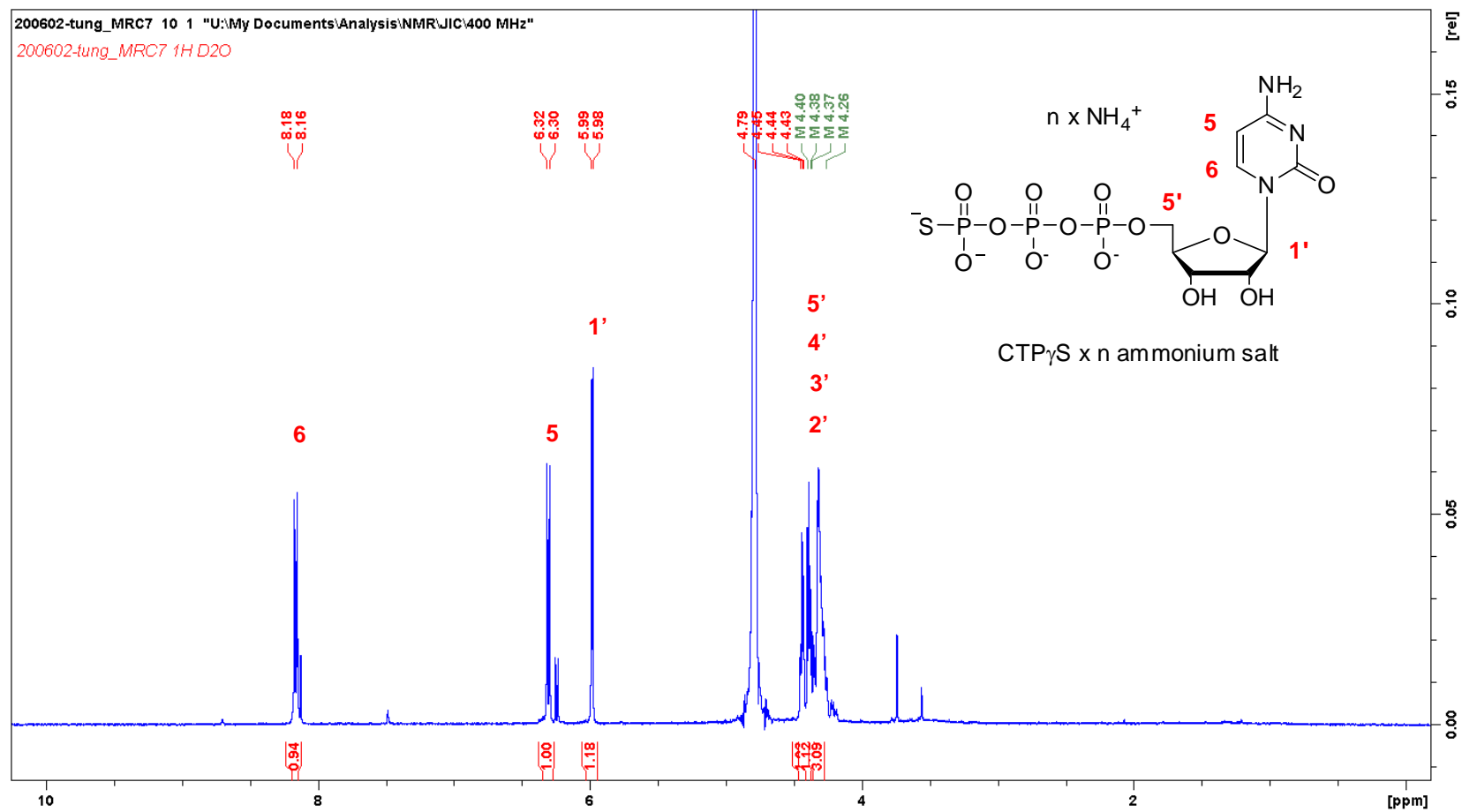

Figure S4. CTPyS $x \mathrm{n}$ ammonium salt: ${ }^{1} \mathrm{H}$ NMR $\left(400 \mathrm{MHz}, \mathrm{D}_{2} \mathrm{O}\right)$ 


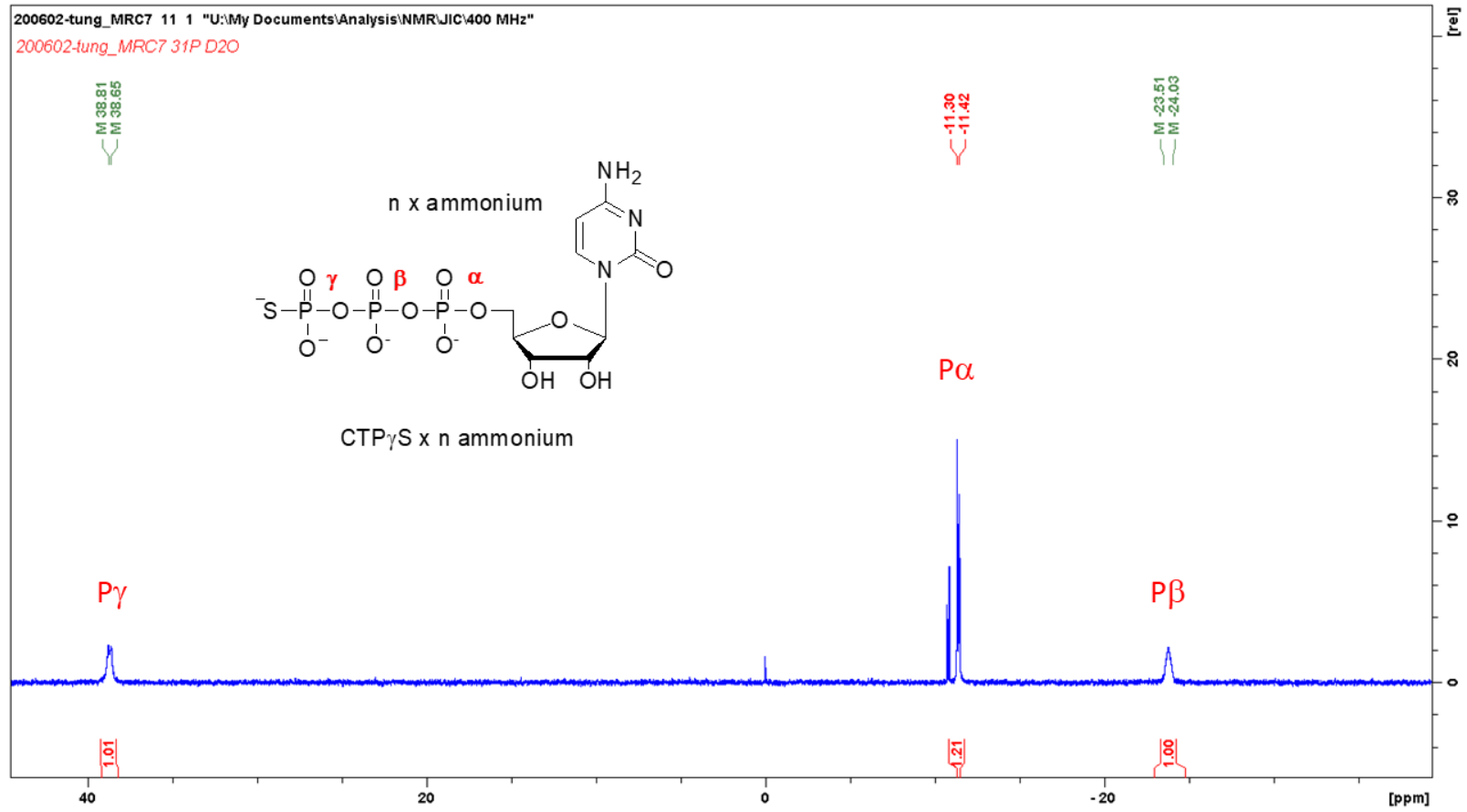

Figure S5. CTPyS x n ammonium salt: ${ }^{31} \mathrm{P}\{1 \mathrm{H}\} \mathrm{NMR}\left(162 \mathrm{MHz}, \mathrm{D}_{2} \mathrm{O}\right)$

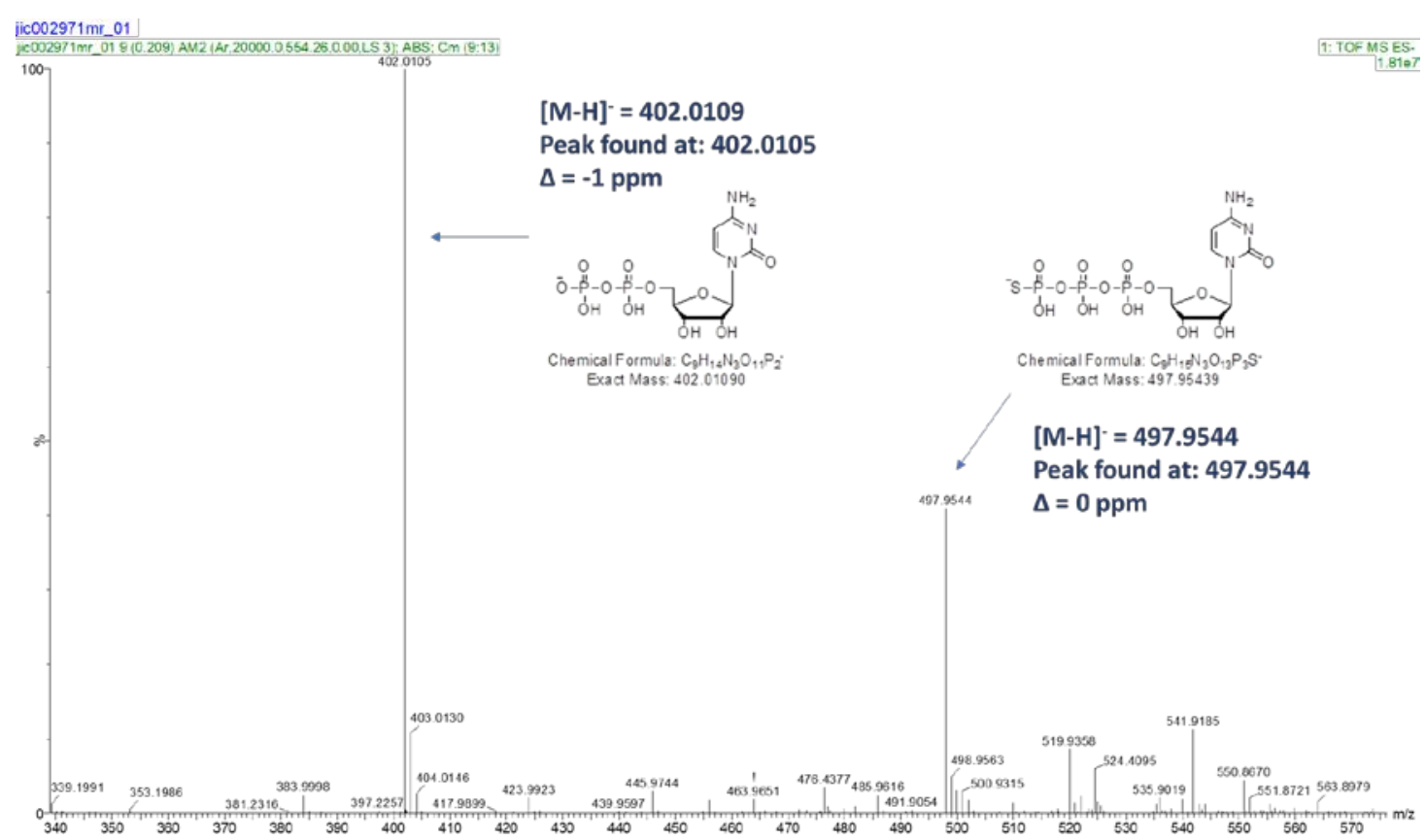

Figure S6. CTPYS: HR-MS (ESI') 